\title{
PEMETAAN LAHAN BERPOTENSI UNTUK MENDUKUNG USULAN PERENCANAAN LAHAN PERTANIAN PANGAN BERKELANJUTAN (STUDI KASUS: PROVINSI JAWA BARAT)
}

\section{Mapping of Potential Land for Supporting Proposal of the Planning of Sustainable Food Based Agricultural Land (A Case Study in West Java Province)}

\author{
Dwi Ratnawati Christina1), Ernan Rustiadi2), dan Baba Barus ${ }^{2}{ }^{*}$
}

1) Direktorat Perluasan Areal, Direktorat Jendral Tanaman Pangan, Kementrian Pertanian, RI 2) Departemen Ilmu Tanah dan Sumberdaya Lahan, Fakultas Pertanian, IPB, Jl. Meranti Kampus IPB Darmaga, Bogor 16680

\begin{abstract}
The passing of Law 41, 2009 on the Protection of Sustainable Food based Agricultural Land (PSFAL) is expected to control the pace of agricultural landuse change inparticular fields. This law is still new so that many of its implementation have not been realized, including the planning and establishment of regions, prime land and reserve land. West Java Province is the provinces second-largest contributor to the national rice with large area of rice paddy field. Spatial analysis can be used to determine the potential of sustainable food based agricultural in province based on data and supporting information. The purposes of this study were (1) to collect data and information for identifying potential sustainable food farming land, (2) to identify potential food based agricultural land at the provincial and district levels, and (3) to develop data and information of potential sites to be proposed as the sustainable food agricultural region, prime food agricultural land and reserve food agricultural land at the provincial and district levels. The results showed that the main factor indeciding of sustainable food agricultural area is the availability of land. Attheprovincial level, the results show that more general planning area proposed, including assemblage of some small regions, and indication of prime and reserve land. The proposed planning at the provincial level is a reference in the preparation of the proposed planning district, with more detail data for regions, prime and reserve land along with prediction size of area. At district level, the implementation of the PSFAL should be integrated with community participation.
\end{abstract}

Keywords: Potential land, prime and reserve land, region, spatial analysis, sustainable food farming

\begin{abstract}
ABSTRAK
Dengan dibuatnya UU No 41, 2009 tentang Perlindungan Lahan Pertanian Pangan Berkelanjutan (PLP2B) diharapkan mampu mengontrol kecepatan konversi lahan sawah ke penggunaan lain. Peraturan ini masih baru sehingga belum banyak diimplementasikan, termasuk penentuan wilayah, lahan utama dan lahan cadangan. Jawa Barat adalah provinsi kontributor pangan beras terbesar secara nasional, yang didukung dengan adanya lahan sawah yang potensial. Analisis spasial dapat digunakan untuk menentukan daerah lahan potensial pertanian pangan berkelanjutan di provinsi berbasis data dan informasi pendukung. Tujuan studi ini adalah (1) menginventarisasi data dan informasi untuk identifikasi lahan potensial perlindungan lahan pangan berkelanjutan, (2) mengindentifikasi lahan pangan potensial di tingkat provinsi dan kabupaten, dan (3) mengembangkan data dan informasi lokasi potensial untuk diusulkan menjadi kawasan, lahan pangan utama dan lahan cadangan perlindungan lahan pangan berkelanjutan pada tingkat provinsi dan kabupaten. Hasil studi menunjukkan bahwa faktor utama dalam penentuan daerah pertanian pangan berkelanjutan adalah ketersediaan lahan. Di tingkat provinsi, hasil menunjukkan adanya usulan perencanan wilayah yang umum, termasuk penggabungan beberapa kawasan yang kecil dan indikasi adanya daerah lahan utama dan cadangan. Usulan perencanaan pada tingkat provinsi dapat dipakai sebagai referensi dalam persiapan usulan pada tingkat kabupaten, dengan data yang lebih detil pada kawasan, lahan utama dan cadangan, bersamaan dengan prediksi luasan lahan. Pada tingkat kabupaten, implementasi PLP2B sebaiknya diintergrasikan dengan partisipasi masyarakat.
\end{abstract}

Kata kunci: Lahan potensial, lahan cadangan, kawasan, analisis spasial, lahan utama

\section{PENDAHULUAN}

Provinsi Jawa Barat merupakan provinsi penyumbang beras nasional nomor dua setelah provinsi
Jawa Timur. Kontribusi beras pada tahun 2008 sebesar $16.8 \%$ dari produksi nasional. Produksi beras ini didukung oleh luas lahan sawah yang ada di daerah ini. Luas baku sawah sebesar 925,900 ha sebagian besar merupakan lahan 
irigasi teknis(41\%), tadah hujan $(18.8 \%)$, irigasi perdesaan $(17.1 \%)$, irigasi setengah teknis $(12.6 \%)$, sisanya irigasi sederhana $(1.0 \%)$ dan sawah pasang surut $(0.4 \%)$. Selama tahun 1994-2005 telah terjadi perubahan lahan sawah ke peruntukan lain seluas 202,975 ha. Potensi hilangnya lahan produktif di wilayah ini sangat besar apabila dilihat dari jumlah penduduknya sebanyak 43,021,826 jiwa atau terbesar di Indonesia (18.1\%) (Bappeda Provinsi Jawa Barat, 2010). Penataan ruang merupakan salah satu kebijakan yang mampu mengendalikan laju alih fungsi lahan pertanian. Dalam Undang-Undang Nomor 26 tahun 2007 tentang Penataan Ruang diamanatkan peraturan mengenai lahan pertanian abadi. Amanat tersebut telah dilaksanakan dengan disahkannya Undang-Undang Nomor 41 Tahun 2009 tentang Perlindungan Lahan Pertanian Pangan Berkelanjutan (PLP2B). Dengan terbitnya UU ini, diharapkan dapat menekan tingginya laju alih fungsi lahan pertanian sawah. Apabila laju alih fungsi lahan pertanian dapat dikendalikan diharapkan fungsi lain seperti fungsi ekologi dapat dipertahankan dan dijaga keberadaannya, dan sudah diterapkan di beberapa negara lain (Pasour, 1982).

Tahapan pertama penyelenggaraan Perlindungan LP2B adalah menentukan dan menetapkan lahan pertanian menjadi tiga komponen, yaitu Kawasan P2B (KP2B), Lahan P2B (LP2B) dan Lahan Cadangan P2B (LCP2B). Dalam Kawasan P2B dapat terdiri dari LP2B dan atau LCP2B. Perencanaan ini diawali dengan penyusunan usulan rencana oleh Pemerintah, Pemerintah Daerah Provinsi, dan Pemerintah Daerah Kabupaten/Kota. Kesulitan utama dalam melakukan penyusunan ketiga komponen tersebut adalah belum adanya kriteria teknis penyusunan kawasan atau lahan P2B (Departemen Pertanian, 2009).

Perencanaan LP2B ini dilakukan dalam berbagai tingkatan yaitu kabupaten/kota, provinsi, dan nasional. Hal ini membawa konsekuensi adanya beberapa tingkatan spasial. Permasalahan dalam perencanaan wilayah adalah bagaimana membuat perencanaan wilayah perdesaan tersebut berbeda namun masih dalam satu kerangka kerja yang sama. Tingkatan tertinggi harus bersifat lebih umum dan menjadi acuan bagi rencana pembangunan tingkatan dibawahnya. Metode yang dimodifikasi perlu digunakan dalam perencanaan regional dan lokal agar mampu memperlihatkan konsekuensi dari perbedaan tingkatan tersebut. Sistem Informasi Geografi (SIG) dan pendekatan model sangat efisien untuk digunakan dalam permasalahan tersebut (Osinski dan Hermann, 1999).

Selain itu, SIG dan pendekatan model dapat juga digunakan untuk melakukan delineasi lahan-lahan pertanian yang sesuai dengan komoditas tertentu. Salah satu aplikasinya adalah pendekatan Multi Criteria Evaluation yang mampu digunakan untuk mengidentifikasi wilayah yang sesuai untuk komoditas tertentu (Ceballos-Silva dan Lo'pez-Blanco, 2003; Munda, 2006). Tujuan penelitian ini adalah (1) inventarisasi data dan informasi yang dapat digunakan dalam identifikasi potensi LP2B, (2) melakukan identifikasi lahan pertanian pangan potensial di tingkat provinsi dan kabupaten, dan (3) menyusun data dan informasi lokasi-lokasi potensial untuk diusulkan sebagai KP2B, LP2B, dan LCP2B di tingkat provinsi dan kabupaten.

\section{BAHAN DAN METODE}

Penelitian dilaksanakan di Provinsi Jawa Barat. Data yang digunakan adalah data sekunder yang terdiri dari data tabulasi dan data spasial yang diperoleh dari berbagai instansi, baik pemerintah maupun non pemerintah di daerah maupun pusat.

Analisis data meliputi: (1) proyeksi kebutuhan lahan sawah dan (2) analisis spasial yang terdiri atas (a) identifikasi dan pemetaan lahan potensial untuk LCP2B, (b) identifikasi dan pemetaan lahan potensial untuk LP2B, dan (c) identifikasi dan pemetaan kawasan potensial untuk KP2B. Analisis data tersebut dilakukan pada dua tingkatan yaitu provinsi $(1: 250,000)$ dan kabupaten $(1: 50,000)$.

Proyeksi kebutuhan lahan dilakukan berdasarkan pada (a) Pertumbuhan penduduk dan kebutuhan konsumsi pangan penduduk, (b) Pertumbuhan produktivitas, (c) Kebutuhan pangan nasional/provinsi. Penghitungan dilakukan sesuai jangka waktu yang perencanaan yaitu tahunan, jangka menengah dan jangka panjang dengan 2 skenario yaitu optimis dan pesimis. Skenario pesimis menggunakan kriteria konsumsi beras per kapita $140 \mathrm{~kg}^{-1}$ kapita $^{-1}$ tahun $^{-1}$, produktivitas tetap, dan intensitas pertanaman tetap, sedangkan skenario optimis menggunakan kriteria konsumsi beras per kapita $139 \mathrm{~kg}^{-1}$ kapita $^{-1}$ tahun $^{-1}$, produktivitas naik sesuai rata-rata kenaikan 10 tahun terakhir, dan intensitas pertanaman naik $1 \%$ per tahun.

Pemetaan lahan potensial untuk LCP2B pada tingkat kabupaten adalah untuk mengetahui sebaran lokasi dan indikasi luas sementara tingkat provinsi hanya untuk mengetahui indikasi luas saja. Kriteria yang digunakan adalah lahan potensial, tidak berada dalam kawasan hutan dan mempunyai kesesuaian lahan sesuai dan sesuai bersyarat. Kesesuaian lahan ini dipakai sebagai landasan untuk penentuan daya dukung yang diamanatkan peraturan penataan ruang (Firdian, 2011). Pemetaan ini menggunakan basis model SIG seperti pada Gambar 1.

Identifikasi lahan potensial untuk LP2B provinsi maupun kabupaten dilakukan dengan kriteria penutupan/penggunaan lahan, kesesuaian lahan, status irigasi, dan intensitas pertanaman. Identifikasi ini menggunakan 2 basis model SIG seperti tertera pada Gambar 2 dan 3. Pada model 1, proses penggabungan akhir dilakukan dengan 4 faktor dengan 2 pilihan pembobot, sedangkan pada model 2, proses penggabungan akhir dilakukan dengan 2 faktor dengan 3 pilihan pembobot.

Metode penentuan nilai terbaik menggunakan metode pembobotan, seperti disajikan sebagai berikut:

Nilai Skor $=\left(A * A_{i}\right)+\left(S * S_{i}\right)+\left(I * I_{i}\right)+\left(C I * C I_{i}\right) \ldots \ldots \ldots \ldots .(1)$

$$
\begin{aligned}
& \text { dimana: } \\
& \mathrm{A}=\text { Lahan Tersedia (Availability) } \\
& \mathrm{S}=\text { Kesesuaian Lahan (Suitability) } \\
& \mathrm{I}=\text { Irigasi (Irrigation) } \\
& \mathrm{CI}=\text { Intensitas Pertanaman (CropIntensity) }
\end{aligned}
$$

Dengan menggunakan 2 nilai pembobot yaitu :

1) nilai pembobot sama atau $\mathrm{A}=\mathrm{S}=\mathrm{I}=\mathrm{CI}=0.250$

2) berbasis biaya pembangunan/rehabilitasi $A=0.092$; $\mathrm{S}=0.104 ; \mathrm{I}=0.432 ; \mathrm{CI}=0.372$. 
Nilai Skor $=\left(S^{*} S_{i}\right)+\left(I^{*} I_{i}\right)+\left(C I^{*} C I_{i}\right)$

Dengan menggunakan 3 nilai pembobot yaitu :

1) Nilai pembobot sama yaitu $\mathrm{A}=\mathrm{S}=\mathrm{I}=\mathrm{CI}=0.333$

2) Berbasis biaya pembangunan/rehabilitasi yaitu $\mathrm{S}=0.114 ; \mathrm{I}=0.476 ; \mathrm{CI}=0.410$

3) Berbasis data empirik yaitu $S=0.280 ; \quad I=0.360$; $\mathrm{CI}=0.360$

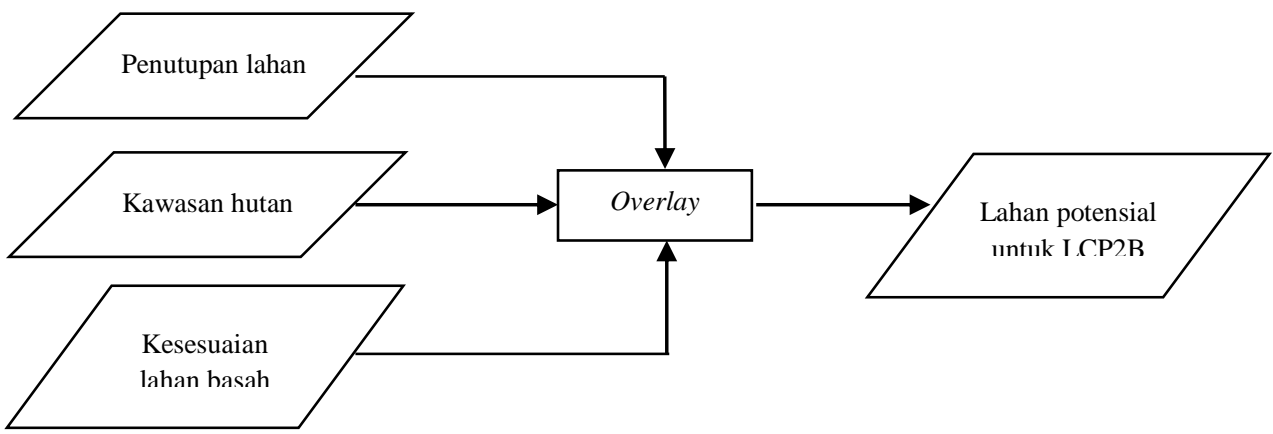

Gambar 1. Basis model konsep pemetaaan lahan potensial untuk LCP2B

Model 1
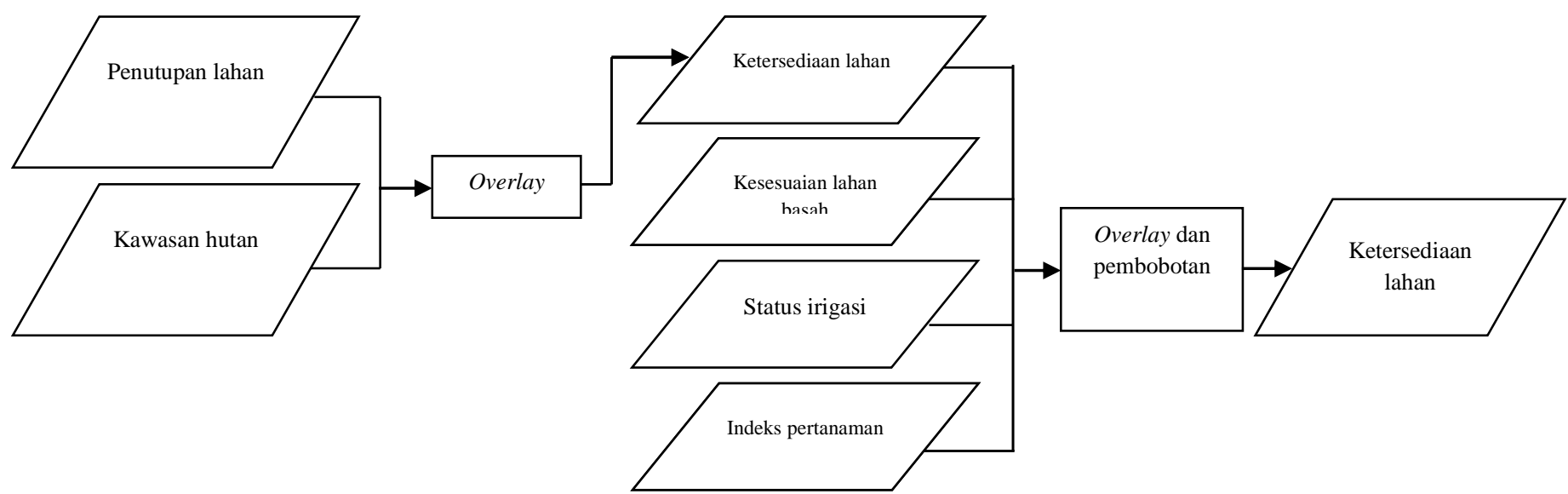

Gambar 2. Basis model 1 konsep pemetaan lahan potensial untuk LP2B

Model 2

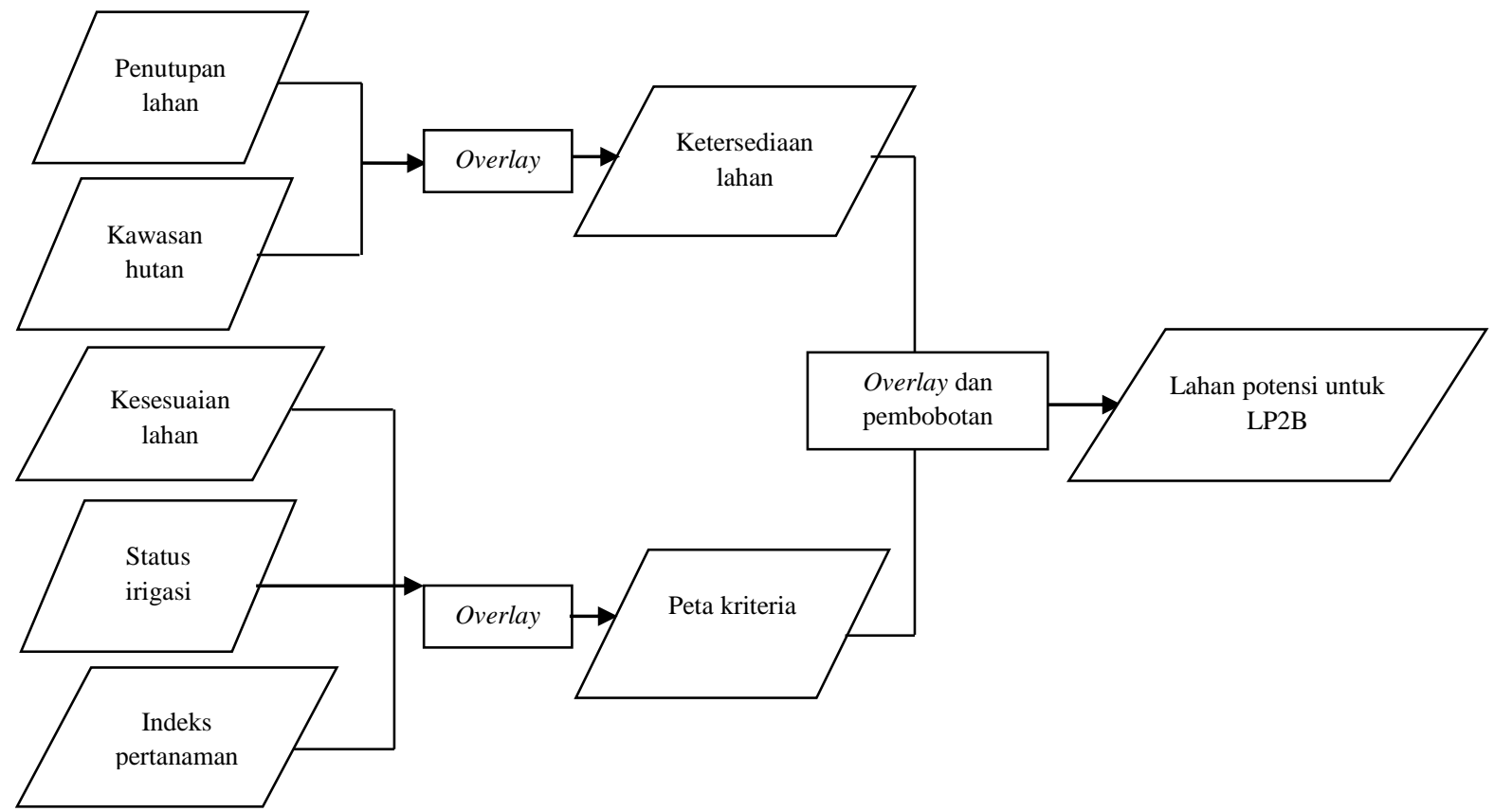

Gambar 3. Basis model 2 konsep pemetaan lahan potensial untuk LP2B 


\section{HASIL DAN PEMBAHASAN}

\section{Proyeksi Kebutuhan Lahan Sawah}

Di Provinsi Jawa Barat dan Kabupaten Garut, dengan menggunakan 2 skenario yaitu pesimis dan optimis, kebutuhan lahan sawah tiap tahunnya semakin menurun seperti tertera pada Gambar 4. Penurunan kebutuhan lahan sawah untuk skenario optimis terjadi karena perluasan areal tanam dan kenaikan produktivitas sementara untuk skenario pesimis disebabkan oleh perluasan areal tanam $1 \%$ per tahun. Ini menandakan bahwa dengan perbaikan prasana pendukung pertanian seperti jaringan irigasi dan kemajuan ilmu pengetahuan dan teknologi mampu mengatasi kebutuhan pangan.

Dari kedua skenario tersebut seperti terlihat pada Gambar 4, kebutuhan lahan sawah untuk mencukupi kebutuhan pangan sendiri maupun kebutuhan pangan nasional sampai tahun 2030 belum melampaui ketersediaan lahan sawah. Provinsi dan kabupaten ini masih mampu mencukupi kebutuhan sendiri dan nasional sehingga tidak perlu menambah luas baku lahan sawah. Hal yang perlu dilakukan adalah pemeliharaan dan perbaikan jaringan irigasi yang ada.

Untuk Kabupaten Garut, secara keseluruhan terjadi penurunan kebutuhan lahan sawah kecuali pada skenario pesimis untuk mencukupi kebutuhan sendiri (sufficient pesimis) terjadi kecenderungan kenaikan kebutuhan lahan sawah. Selain itu, kontribusi untuk mencukupi kebutuhan provinsi justru melebihi kebutuhan sendiri dimulai pada tahun 2019. Selain disebabkan oleh tingginya angka konsumsi beras juga oleh laju pertumbuhan penduduk (LPP) yang tinggi yaitu $1.59 \%$ selama 10 tahun terakhir. Laju pertumbuhan ini berada diatas LPP Indonesia (1.49\%). Hal tersebut perlu mendapat perhatian, sebab kemungkinan bisa terjadi kabupaten ini tidak mampu menyediakan lahannya untuk kebutuhan pangannya sendiri. Untuk itu perlu kebijakan pemerintah daerah setempat dalam pengendalian laju pertumbuhan penduduk dan diversifikasi pangan.

\section{Identifikasi dan Pemetaan Lahan Potensial Untuk LCP2B}

Skala yang digunakan dalam pemetaan tingkat provinsi adalah skala 1:250,000. Skala ini disesuaikan dengan peta rencana umum tata ruang wilayah provinsi. Selain itu juga disesuaikan dengan ketersediaan peta yang ada. Hasil pemetaan lahan cadangan pertanian pangan berkelanjutan potensial ini menunjukkan bahwa lahan yang berpotensi untuk dicadangkan sebagai lahan pertanian pangan berkelanjutan di Provinsi Jawa Barat seluas 780,848 ha atau $64.6 \%$ dari total lahan potensial yang ada $(1,227,769$ ha). Kabupaten Sukabumi merupakan kabupaten yang diindikasikan memiliki luas lahan terluas 170,520 ha atau $21.8 \%$.

Skala yang digunakan dalam pemetaan kabupaten adalah 1:50,000. Skala ini disesuaikan dengan peta rencana umum tata ruang wilayah kabupaten. DAS Cimanuk Hulu dipilih menjadi lokasi penelitian di Kabupaten Garut karena daerah di sekitar DAS ini merupakan daerah sentra produksi padi dan memiliki luas sawah terluas di Kabupaten Garut. Berdasarkan kriteria pemilihan LCP2B potensial maka lahan yang sesuai seluas 21,998 ha atau seluruh lahan potensial yang ada. Di wilayah hutan, areal yang kelas kesesuaiannya S2 dan S3 seluas 4,417 ha. Perlu penelitian lebih lanjut mengenai status kawasan ini apabila lahan tersebut akan dimanfaatkan sebagai lahan pertanian.

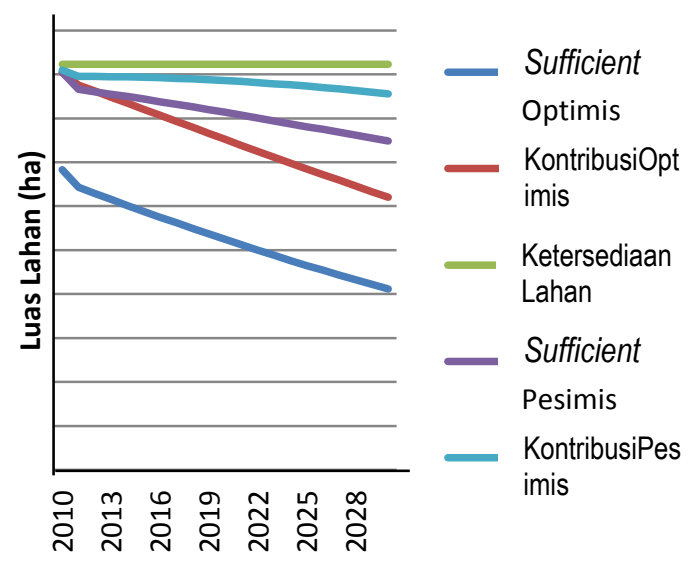

a. Jawa Barat

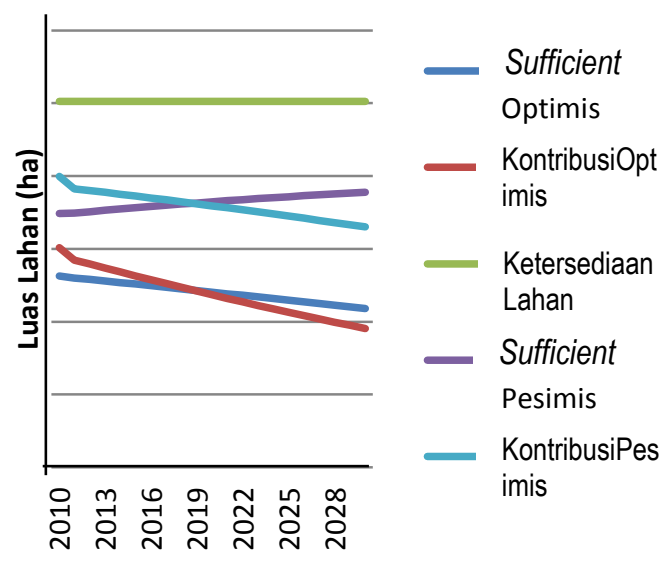

b. Garut

Gambar 4. Proyeksi kebutuhan lahan sawah 


\section{Identifikasi dan Pemetaan Lahan Potensial Untuk LP2B}

Pemetaan untuk tingkat provinsi dilakukan menggunakan dua model SIG. Pada model pertama diperoleh hasil bahwa dengan nilai pembobot berdasarkan biaya pembangunan/rehabilitasi memiliki kelas skor yang lebih banyak (13 kelas skor) sehingga data yang diperoleh lebih rinci. Berdasarkan faktor pembatas ketersediaan lahan, kedua hasil pembobot memberikan nilai yang sama. Pada kelas skor 3 terakhir merupakan kelas skor terbaik dengan luasan lahan seluas 522,639 ha. Kriterianya adalah sawah yang ada, memiliki irigasi, IP (Index Pertanaman) > 1x tanam per tahun, dan kelas kesesuaiannya $\mathrm{S}$ (sesuai), V (sesuai bersyarat), dan $\mathrm{N}$ (tidak sesuai). Luas lahan potensial untuk LP2B yang dipilih adalah daerah yang berkelas sesuai dan sesuai bersyarat, dengan luasan total adalah 502,071 ha.

Model kedua digunakan untuk memenuhi kebutuhan lahan sawah sesuai dengan kebutuhan LP2B. Sesuai dengan perencanaan LP2B maka jumlah lahan yang harus dilindungi pada tahun 2011 dari kemungkinan konversi lahan sawah ke komoditas ataupun peruntukan bukan sawah untuk skenario pesimis adalah sufficient= 865,510 ha dan kontribusi $=895,015$ ha, sementara skenario optimis adalah sufficient $=642,928$ ha dan kontribusi $=875,658$ ha. Dari hasil ketiga pembobot diatas angka yang mendekati adalah 843,393 ha. Lahan sawah yang tidak dilindungi seluas 79,826 ha merupakan lahan sawah nonirigasi. Dalam model ini lahan yang dilindungi termasuk lahan-lahan sawah yang menurut kelas kesesuaian lahan tidak sesuai (N). Dalam hal ini sawah yang berada di lahan tidak sesuai sudah ada dan tinggal mengelola.

Dari hasil pemetaan kedua model dapat diketahui bahwa model pertama merupakan model yang dapat mengidentifikasi sesuai dengan kriteria yang ditetapkan dalam peraturan, sehingga lahan yang terpilih merupakan lahan terbaik yang didukung oleh kondisi alamiah dan fisik serta infrastruktur yang baik sehingga diharapkan produktivitas lahannya pun tinggi. Kekurangannya adalah tidak mampu memenuhi kebutuhan lahan sawah di Provinsi Jawa Barat. Dengan model tersebut hanya mampu memenuhi $78.1 \%$ lahan sawah yang dibutuhkan untuk pemenuhan kebutuhan sendiri. Kekurangan ini dapat dipenuhi dengan menambah lahan potensial untuk LCP2B namun akan memerlukan biaya yang sangat besar.

Pada model kedua, keunggulannya antara lain seluruh lahan sawah irigasi dapat dilindungi sehingga dapat mengurangi biaya pembangunan jaringan irigasi, mampu memenuhi kebutuhan perencanaan, baik tahunan, jangka menengah dan panjang. Selain itu model ini lebih mudah dan cepat dalam pengelolaan data dan informasi karena cakupan data dan informasi lebih sedikit. Kekurangannya adalah tidak sesuai dengan kriteria yang ditetapkan, dan jika model ini digunakan maka hampir seluruh lahan sawah ditetapkan untuk dilindungi tanpa perlu melihat kesesuaian lahannya.

Untuk pemetaan tingkat kabupaten, pemetaan model 1 menggunakan nilai pembobot yang berimbang. Faktor pembatas pada model 1 ini adalah ketersediaan lahan. Hasil pembobotan tersebut adalah pada nilai skor 0.441-0.592 semua lahan tersedia, untuk nilai skor dibawahnya tercampur antara lahan tersedia dan tidak tersedia. Luasan lahannya seluas 19,468 ha dengan kriteria terendah sawah, N2, irigasi teknis, dan IP 1x tanam/tahun. Nilai skor besar pada lahan berkesesuaian rendah ini akibat adanya irigasi. Sementara apabila mengacu pada kriteria bahwa LP2B harus memiliki kelas kesesuaian lahan S1, S2, S3 maka hanya 1 kelas skor yang memenuhi syarat yaitu 0.592 dengan kriteria sawah aktual, S3, irigasi teknis, dan IP 2x tanam/tahun seluas 15,486 ha. Pada model 2, nilai pembobot yang hampir sama menyebabkan hasilnya pun hampir sama. Perbedaannya hanyalah pada rentang nilai skor. Pada model ini, 2 nilai skor tertinggi seluas 16,022 ha merupakan lahan potensial ideal dengan kriteria teknis kelas kesesuaian lahan S3, teknis dan semi teknis, dan IP 2x tanam/tahun.

Berdasarkan perhitungan kebutuhan lahan sawah Kab. Garut pada tahun 2011 untuk skenario optimis ( sufficient $=26,002$ ha dan kontribusi $=28,454$ ha) dan skenario pesimis (sufficient $=34,921$ ha dan kontribusi= 38,215 ha), tidak ada lahan potensial ideal pada kedua model memenuhi kebutuhan tersebut. Hal tersebut disebabkan oleh kriteria kelas kesesuaian lahan yang harus S1, S2, dan S3. Penelitian terdahulu menyatakan bahwa lahan pada DAS Cimanuk Hulu tidak ada yang tergolong S1 dan hanya sebagian kecil saja yang tergolong S2, sedangkan sebagian besar sisanya tergolong S3. Pembatasnya adalah drainase tanah yang tergolong cepat. Namun hal ini bukan menjadi penghalang bagi masyarakat sekitar untuk memanfaatkannya menjadi sawah. Sawah telah ada sejak lama karena mendapat pengairan yang berlimpah akibat curah hujan yang cukup tinggi dan adanya irigasi teknis dan semi-teknis sehingga kebutuhan air atau kelembaban tetap terpelihara. Dari hasil pemetaan tersebut dapat diketahui bahwa perlakukan perbaikan terhadap faktor pembatas kesesuaian lahan mampu meningkatkan nilai skor.

Untuk memenuhi kebutuhan lahan sawah maka kelas kesesuaian lahan dapat diabaikan sehingga model kedua dapat digunakan. Model ini lebih mudah digunakan untuk memenuhi kebutuhan lahan sawah sesuai dengan jangka waktu perencanaan LP2B dibanding model 1. Sementara skenario yang digunakan adalah skenario optimis, dengan skenario ini kebutuhan lahan sawah dapat terpenuhi. Untuk kontribusi ke provinsi, lokasi lahan potensial dapat dialokasikan ke wilayah di luar DAS. Dari hasil kedua pembobot diatas angka yang mendekati adalah 28,718 ha. Lahan sawah yang tidak dilindungi seluas 4,541 ha merupakan lahan sawah non irigasi. Sebaran lokasi lahan potensial untuk LP2B dab LCP2B DAS Cimanuk Hulu tertera pada Gambar 5. 


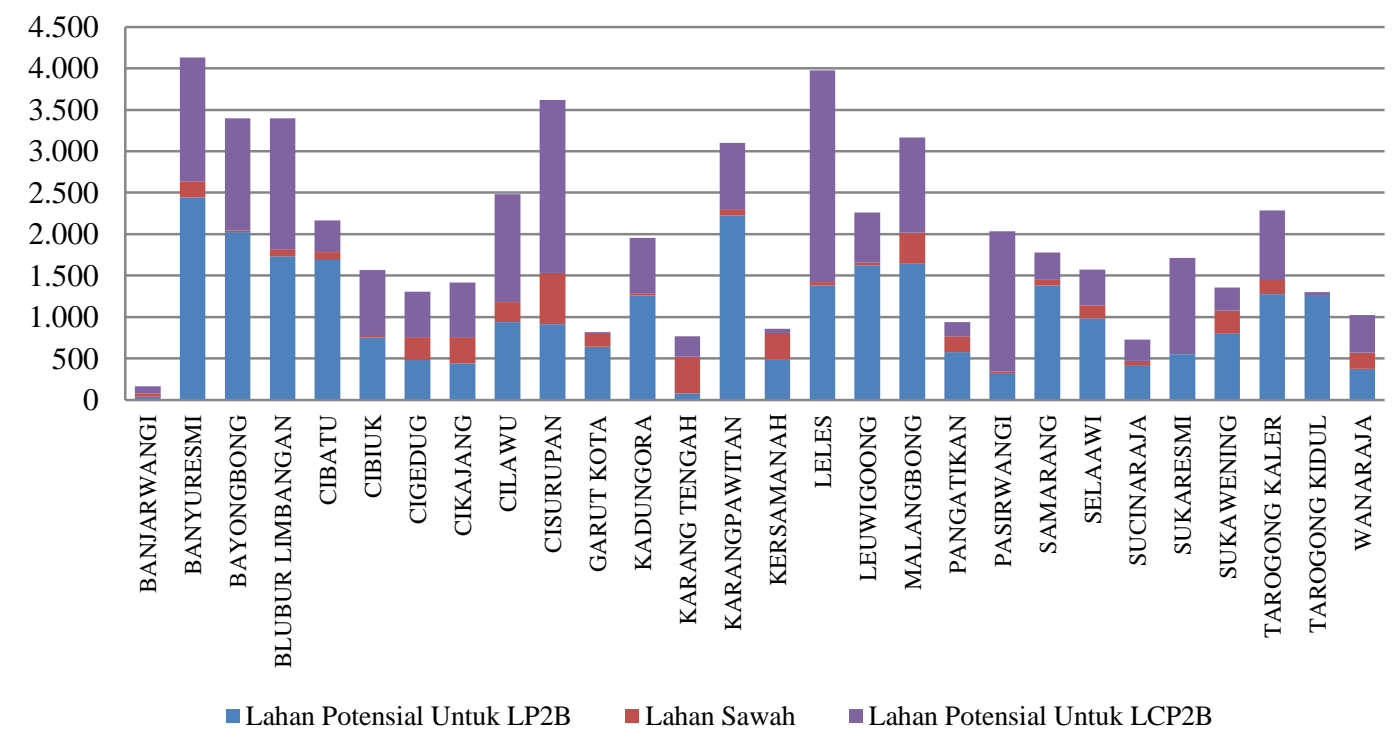

Gambar 5. Sebaran lokasi lahan potensial untuk LP2B dan LCP2B DAS Cimanuk Hulu Kabupaten Garut

\section{Identifikasi dan Pemetaan Kawasan Potensial Untuk KP2B}

Pemetaan kawasan potensial untuk KP2B pada tingkat provinsi terdiri atas kawasan potensial untuk kawasan P2B Nasional (KP2BN), Provinsi (KP2BP), dan Kabupaten/Kota (KP2BK). Untuk model provinsi 1, teridentifikasi $2 \mathrm{KP} 2 \mathrm{BN}, 6 \mathrm{KP} 2 \mathrm{BP}$, dan $8 \mathrm{KP} 2 \mathrm{~K}$ sementara model provinsi 2 mengidentifikasikan $2 \mathrm{KP} 2 \mathrm{BN}, 9$ KP2BP, dan $10 \mathrm{KP} 2 \mathrm{~K}$ (Gambar 6 dan 7). Penentuan KP2BN didasarkan pada lokasi kawasan. KP2BN 1 dan 2 terletak di wilayah perbatasan sehingga dimungkinkan adanya kawasan antar provinsi.

Kawasan potensial ini tidak memperhatikan batas administrasi, pada KP2BP dalam 1 kawasan terdiri atas 26 kabupaten/kota hampir sama dengan KP2BN yang terdiri $>2$ kabupaten dan luasan yang sangat luas. Model provinsi 2 lebih banyak memiliki kawasan potensial karena luasan lahan potensial LP2B dan LCP2B lebih luas dibandingkan dengan model 1.

Dari delineasi potensi KP2B dapat diketahui karakteristik potensi masing-masing KP2B sebagaimana disajikan pada Tabel 1.

Tabel 1. Karakteristik potensi KP2B Provinsi Jawa Barat

\begin{tabular}{lll}
\hline & \multicolumn{1}{c}{ Model 1 } & \multicolumn{1}{c}{ Model 2 } \\
\hline Jumlah & 2 KP2BN,6 KP2BP, 8 & 2 KP2BN, 9 KP2BP, \\
Kawasan & KP2BK & 10 KP2BK \\
& KP2BN : 246,448 ha & KP2BN : 53,389 ha \\
Luas Rata-rata & KP2BP: 55,933 ha & KP2BP : 37,223 ha \\
& KP2BK : 31,910 ha & KP2BK : 14,447 ha \\
& KP2BN : 43,260 ha & KP2BN : 25,201 ha \\
Luas Minimum & KP2BP : 22,071 ha & KP2BP : 3,575 ha \\
& KP2BK : 12,748 ha & KP2BK : 4,935 ha \\
Luas & KP2BN : 449,636 ha & KP2BN : 347,878 ha \\
Maksimum & KP2BP : 130,587 ha & KP2BP : 87,324 ha \\
\% LP2B di & $80.6 \%$ & KP2BK : 13,426 ha \\
dalam Kawasan & & $75.9 \%$ \\
\% LP2B di luar & $19.4 \%$ & $24.1 \%$ \\
Kawasan & $20 \mathrm{kab} / \mathrm{kota}$ & $21 \mathrm{kab} / \mathrm{kota}$ \\
Tingkat Sebaran & \multicolumn{2}{l}{} \\
\hline
\end{tabular}

Pemetaan potensi kawasan kabupaten dilakukan dengan mendeliniasi secara visual dengan berdasarkan pada spatialcontiguity dan compactness. Pada delineasi model 1 diidentifikasi 4 wilayah potensial untuk KP2B sedangkan model 2 dapat diidentifikasi 3 wilayah potensial (Gambar 7). Pada model 2, jumlah potensi kawasan lebih sedikit namun luas potensi LCP2B dan LP2B lebih luas dibandingkan dengan model 1.

Dari delineasi kawasan potensial untuk KP2B dapat diketahui karakteristik KP2B sebagaimana disajikan pada Tabel 2.

Tabel 2. Karakteristik potensi KP2B DAS Cimanuk Hulu

\begin{tabular}{lcc}
\hline & Model 1 & Model 2 \\
\hline Jumlah Kawasan & 4 KP2BK & 3 KP2BK \\
Luas Rata-rata (ha) & 3,935 & 7,075 \\
Luas Minimal (ha) & 1,109 & 3,539 \\
Luas Maksimal (ha) & 6,100 & 8,391 \\
LP2B di dalam Kawasan & $56.5 \%$ & $63.6 \%$ \\
LP2B di luar Kawasan & $43.5 \%$ & $36.4 \%$ \\
Tingkat Sebaran & 23 Kecamatan & 23 Kecamatan \\
\hline
\end{tabular}

Luas kawasan yang paling kecil adalah potensi KP2B yang berada dalam satu kecamatan saja sementara untuk yang terluas dari model 1 dan 2 berada lintas kecamatan. Pendeliniasian ini tidak memperhitungkan batas administrasi sehingga ada 2 potensi KP2B yang berada di 10 kecamatan. Dalam penerapan di lapangan, pengelolaan kawasan akan banyak mengalami kendala dalam hal koordinasi pengelolaan. Pengelolaan terutama dalam pelaksanaan kebijakan pemerintah masih diberikan berdasarkan lokasi administrasi. Keuntungan dengan hamparan yang sangat luas ini adalah keterpaduan hamparan sehingga keberlanjutan kawasan ini akan lebih terjaga. 

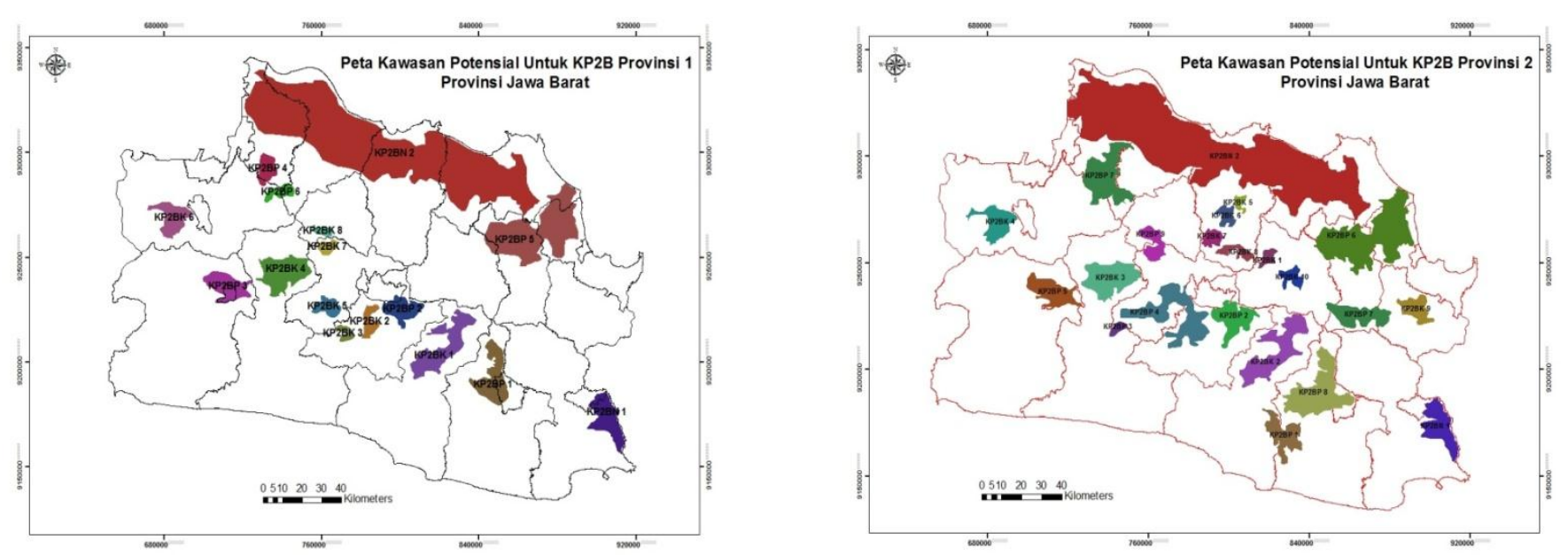

Gambar 6. Peta kawasan potensial untuk KP2B model 1 dan 2 Provinsi Jawa Barat
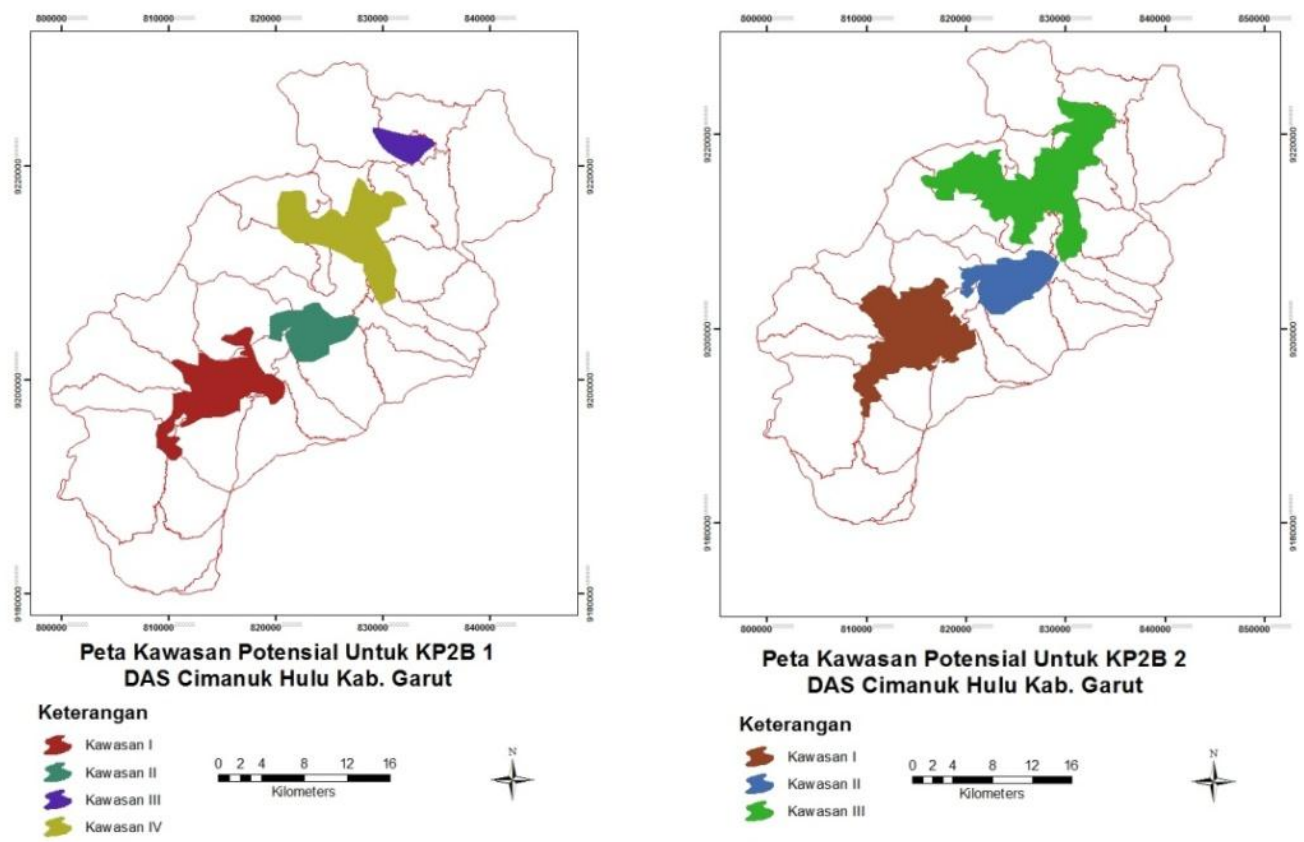

Gambar 7. Peta kawasan potensial untuk KP2B DAS Cimanuk Hulu model 1 dan 2

\section{SIMPULAN}

1. Data dan informasi penggunaan lahan, kesesuaian lahan, status irigasi, dan IP dapat digunakan untuk mengidentifikasi lahan potensial untuk LP2B, LCP2B, dan KP2B.

2. Di Provinsi Jawa Barat teridentifikasi lahan potensial untuk LCP2B di Provinsi Jawa Barat seluas 780,848 ha sementara di Kabupaten Garut seluas 21,998 ha. Dengan menggunakan model 2, teridentifikasi di Jawa Barat memiliki lahan potensial LP2B seluas 843,393 ha dengan kawasan seluas 853,058 ha yang terdiri atas 2 KP2BN, 9 KP2BP, serta $10 \mathrm{KP} 2 \mathrm{BK}$ sementara di Kabupaten Garut memiliki lahan potensial LP2B seluas 28,178 ha dengan kawasan seluas 21,225 ha yang terdiri atas $3 \mathrm{KP} 2 \mathrm{~K}$.
3. Lahan potensial untuk LCP2B dan LP2B tersebar di seluruh kabupaten/kota di Provinsi Jawa Barat. Untuk LCP2B, terluas di Kab. Sukabumi seluas 170,510 ha dan tersempit Kota Cirebon seluas 181 ha. Untuk LCP2B dan LP2B di Garut, Kecamatan Leles memiliki LCP2B terluas yaitu 2,556 ha sementara Kecamatan Banyuresmi memiliki LP2B terluas 2,442 ha. Kecamatan Pakenjeng dan Kecamatan Pamulihan tidak memiliki LP2B dan LCP2B.

\section{SARAN}

1. Identifikasi lahan potensial pada penelitian ini menggunakan data spasial lama seperti status irigasi, intensitas pertanaman, kesesuaian lahan basah sehingga perlu pembaruan data dan informasi. 
2. Perlu dilakukan penelitian yang lebih detil pada lahan potensial yang diusulkan sebagai KP2B, LP2B, dan LP2B karena adanya perbedaan kondisi fisik dan alamiah agar usulan perencanaan tersebut lebih terarah.

3. Untuk pengelolaan kawasan potensial yang berada di 2 provinsi dan beberapa kabupaten/kota memerlukan sinkronisasi dan koordinasi antar instansi terkait baik Pemerintah pusat maupun pemerintah daerah.

\section{DAFTAR PUSTAKA}

Asmuti, A. 1995. Analisis keragaan teknis dan ekonomis beberapa taraf teknis irigasi gravitasi padi sawah (Studi Kasus Irigasi Sumatra Barat). [Tesis]. Institut Pertanian Bogor.

Bappeda Provinsi Jawa Barat. 2010. Materi Teknis RTRW Provinsi Jawa Barat 2009-2029. Bandung.

Departemen Pertanian. 2009. Undang-Undang Nomor 41 Tahun 2009 Tentang Perlindungan Lahan Pertanian Berkelanjutan. Departemen Pertanian. Jakarta.
Ceballos-Silva, A. and J. Lo'pez-Blanco.2003. Delineation of suitable areas for crops using a multi-criteria evaluation approach and landuse/cover mapping: A Case Study in Central Mexico. Agricultural System, 77:117-136.

Firdian, A. 2011. Kajian pola pemanfaatan ruang di kabupaten garut berbasis daya dukung lingkungan hidup. [Tesis]. Institut Pertanian Bogor.

Munda, G. 2006. Socio multi criteria evaluation for urban sustainaibility policies. Land Use Policy, 23:8694.

Pasour, E.C.Jr. 1982. Agricultural land protection: is government intervention waranted. Cato Jurnal, 2:739-758.

Osinski, E and S. Herrmann. 1999. Planning sustainable landuse in rural areas at different spatial levels using GIS and modelling tools. Landscape and Urban Planning, 46:93-101. 